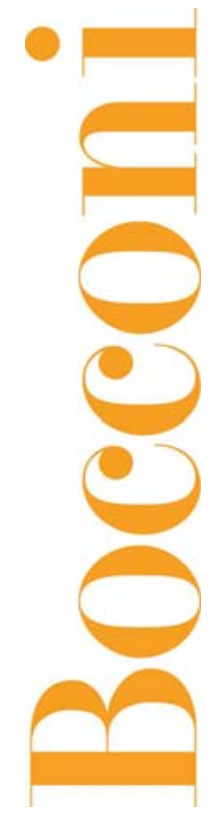

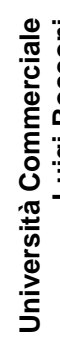

CAREFIN

Centre for Applied Research in Finance

Working Paper

$01 / 2012$

Renato Maino

Vera Palea

Fair Value Measurement for Private Equities: a Plus or a Minus for Stakeholders? 


\section{Fair Value Measurement for Private Equities: a Plus or a Minus for Stakeholders?}

by Renato Maino

Vera Palea

n. $01 / 2012$

Milan, April 2012 


\section{INDEX}

$\begin{array}{lll}\text { Abstract } & \text { II }\end{array}$

1. INTRODUCTION 1

2. IFRS 13 FAIR VALUE DEFINITION AND MEASUREMENT 3

3. MAIN ISSUES RELATED TO FAIR VALUE MEASUREMENT USING VALUATION TECHNIQUES

3.1 Volatility in accounting data 5

$\begin{array}{lll}3.2 & \text { Fair value estimate reliability } & 6\end{array}$

3.3 Economic consequences of estimation errors 6

$\begin{array}{lll}3.4 & \text { Differences between private and public equity performance } & 7\end{array}$

3.5 The strategic intent of private equity investments 8

4. OUR FIELD-TEST 9

4.1 Sample and data $\quad 10$

4.2 Results 11

5. CONCLUSIONS 15

APPENDIX:THE OPTION VALUATION METHODOLOGY 17

$\begin{array}{lr}\text { References } & 20\end{array}$ 


\begin{abstract}
*
In this paper, we discuss the potential economic consequences of IFRS 13 endorsement in the European Union. Our focus is on private equity valuation.

We review prior research and perform a field-test in order to shed light on the possible effects of its adoption.

Our paper questions whether fair value, as defined by IFRS 13, is an appropriate measure for private equities and can effectively contribute to enhance transparency and comparability in financial statement, which is one of the explicit purposes of both the IASB and the European Union Regulation 1606/2002. Our field-test supports this claim and shows that market-based valuation techniques fail to provide fair values which are a faithful representation of the economic real world phenomena they purport to represent. Consistently with previous research, we show that market and transaction multiples do a poor job and relevant entity-specific adjustments will be necessary.
\end{abstract}

\footnotetext{
${ }^{*}$ Renato Maino Department of Finance, Bocconi University, Milan, Italy E-mail: renato.maino@unibocconi.it Vera Palea, University of Turin, Department of Economics “Cognetti de Martiis”, via Po 53, Turin, 10100 Italy. E-mail addresses: vera.palea@unito.it; vera.palea@gmail.com. Phone number: 00390116704406. Fax number: 00390116703895.
} 


\section{1. INTRODUCTION}

Standard setters and extensive academic literature believe that fair value accounting provides the most relevant information to financial statement users (Barth, Beaver and Landsman, 2001). Fair value accounting should ensure a higher degree of transparency of financial statements, which should lead to a higher value-relevance of accounting data and a better capability of financial markets to reflect the actual value of a firm. An extensive use of fair value measurement should increase the quantity of private information brought into public domain, thus leading to a more efficient resource allocation and capital formation.

In 2009 IASB issued IFRS 9, Financial Instruments, which will be effective starting from January, 1 2015. Such a standard has removed the rule that equities which do not have prices quoted in an active market and whose fair value cannot be measured reliably shall be measured at cost. As a result, private equities shall be measured at fair value with no exceptions.

In 2011 IASB issued IFRS 13, Fair Value Measurement, which is the result of a joint project conducted by IASB together with FASB. IFRS 13 sets out a single framework for measuring fair value and provides comprehensive guidance on 'how' to measure fair value, whereas it does not set out requirements on 'when' to apply fair measurement. However, it is clear that any debate about possible future IASB proposal to extend the use of fair value - as for private equities requires fair value to be clearly defined. IFRS 13 also increases the convergence between IFRS and US GAAP through the same definition of fair value as well as an alignment of measurement and disclosure requirements. IFRS 13 will become effective in January 2013.

Neither IFRS 9, nor IFRS 13 have yet been endorsed in the European Union. In order to come into force in the European Union, IFRSs must go through an endorsement process. The endorsement process consists in several steps and involves many institutions at the European level. One of these is the European Financial Reporting Advisory Group (EFRAG), which holds consultation with interest groups and then delivers its advice to the European Commission on whether the new standard meets the criteria of endorsement.

EFRAG evaluates whether the standard is compliant with the principle of 'true and fair view' set out in the IV and VII European Directives and meets the criteria of understandability, relevance, reliability and comparability stated both in the IASB Framework and in the European Union Regulation 1606/2002. In addition, even if it is not specific to report on, EFRAG also gives advice on whether the IFRS under endorsement is conducive to the European public good and, therefore, it is of overall interest to the European Union.

The purpose of this paper is to raise some issues on IFRS 13 related to private equity valuation which, in our opinion, should be taken into account in its endorsement process.

We raise relevant issues on fair value definition as an exit price and on the reliability of market-based valuation techniques. We review prior research and perform a field-test in order to shed light on the potential economic consequences of IFRS 13 adoption.

First, we report studies which document that, as a rule, fair value measurement based on valuation techniques leads to less reliable information, higher expected returns by investors and lower ability to monitor managerial behavior. Therefore, we show that estimation errors bear significant economic consequences. 
Then, we review studies which find that market-based valuation techniques could be misleading for private equities, whose performance is relatively different from publicly traded companies. A market-based, rather than entity specific, fair value measurement fails to consider the financial instrument liquidity and investors' horizons, which are key to private equity valuation.

Finally, we perform a field-study in which we form a portfolio of companies listed on the stock exchange which we treat as private. We apply IFRS 13 and evaluate them according to three different valuation techniques: market multiples, transaction multiples and an option approach. Market and transaction multiples should have greater reliability as they are corroborated by observable market data. For this reason, IFRS 13 includes them in Level 2 fair value hierarchy.

We compare fair value estimates with one another as well as with market prices. We use market prices to test the reliability of different valuation techniques as IFRS 13 states that a quoted price in an active market provides the most reliable fair value. Comparison with actual market prices allows assessment of whether, and how well, changes in private equity fair values measured using valuation techniques incorporate changes in real-world exit prices and, therefore, make financial reporting a reliable reference for financial statement users in order to adjust their own expectations.

Our field-test shows that market-based valuation techniques provide very different portfolio fair values which alter comparison among financial reports, mislead performance analysis and appraisals as well as management choices and compensation. Differences are relevant not only among valuation techniques but also if compared with actual market prices.

In conclusion, we show that the IFRS 13 fair value definition does not result in reliable and decision-useful information. For such a reason, we question whether IFRS 13 is compliant both with the European Union Regulation 1606/2002, whose main purpose is to ensure a high degree of transparency and comparability in financial information, and the IASB Framework, which states that fair value accounting is expected to provide investors with useful information to predict the capacity of firms to generate cash flow from their assets.

Should IFRS 13 be endorsed as currently stated, then the exemption to fair value private equities - as currently provided by IAS 39 - should also be set out in IFRS 9 .

Our findings are of direct interest not only to accounting standard setters, but also to banking regulators as bank capital requirement is largely based on financial report. Therefore, fair value measurement using valuation techniques deserves careful analysis due to its potential effects on the credit cycle and real economy financing.

The remainder of this paper is organized as follows. Section 2 introduces IFRS 13 main requirements which are of research interest, whereas Section 3 discusses the main issues related to private equity valuation and reviews prior research. Section 4 describes our field-test and comments its results, while Section 5 concludes. 


\section{2. IFRS 13 FAIR VALUE DEFINITION AND MEASUREMENT}

IFRS 13 defines fair value as the price that would be received to sell an asset in an orderly transaction between market participants at the measurement date. The definition of fair value in IFRS 13 reflects an exit price notion, that is the market price from the perspective of a market participant who holds the asset.

IFRS 13 points out that fair value must be a market-based, not an entity-specific measurement. Therefore, the firm's intention to hold an asset is completely irrelevant. For instance, the application of blockage factors to a large position of identical financial assets is prohibited given that a decision to sell at a less advantageous price because an entire holding, rather than each instrument individually, is sold represents a factor which is specific to the firm.

If observable market transactions or market information are not directly observable, the objective of fair value measurement still remains the same, that is to estimate an exit price for the asset, and the firm shall use valuation techniques.

Valuation techniques shall be consistent with the market approach, income approach or cost approach. The market approach uses prices and other relevant information generated by market transactions involving identical or comparable assets. The income approach uses valuation techniques to convert future amounts (e.g. cash flows or income and expenses) to a single present amount. According to IFRS 13, such valuation techniques include present value techniques, option pricing models - such as the Black-Scholes-Merton formula and the binomial model - and the multi-period excess earnings method. The cost approach, instead, reflects the current replacement cost, that is the amount that would currently be required to replace the service capacity of an asset.

IFRS 13 categorizes inputs to valuation techniques into a fair value hierarchy which gives the highest priority to quoted prices (unadjusted) in active markets for identical assets (Level 1 inputs) and the lowest priority to unobservable inputs (Level 3 inputs).

Level 1 inputs are quoted prices (unadjusted) in active markets for identical assets that the firm can access at the measurement date. With Level 1 inputs information asymmetry between management and investors is very low. Hence, quoted prices in active markets must be used whenever available.

Level 2 inputs are inputs, other than quoted prices, that are observable - either directly or indirectly - for the asset. Level 2 inputs include quoted prices for similar assets in active markets; quoted prices for identical or similar assets in markets that are not active; inputs other than quoted prices that are observable for the asset, such as interest rates and yield curves observable at commonly quoted intervals, volatilities, prepayment speeds, loss severities, credit risks, default rates; inputs that are derived principally from or corroborated by observable market data by correlation or other means. Level 2 inputs should have great reliability as they are corroborated by observable market data. As such, IFRS 13 require maximum use of observable inputs in determining fair value.

Adjustments to Level 2 inputs that are significant to the entire measurement result in a fair value measurement categorised within Level 3. Level 3 inputs are unobservable inputs for an asset fair value measurement. Unobservable inputs are inputs for which market data are not 
available and, therefore, need to be developed on the basis of the best information available about the assumptions that market participants would use when pricing the asset. Level 3 inputs are subject to the highest degree of information asymmetry between preparers and users.

\section{3.}

\section{MAIN ISSUES RELATED TO FAIR VALUE MEASUREMENT USING VALUATION TECHNIQUES}

Since private equities do not have a directly observable exit price, valuation techniques must be used to measure their fair value. Valuation techniques use Level 2 or Level 3 inputs of the fair value hierarchy.

Many constituencies of the standard setting process have already raised the issue that it could be very difficult, or even impossible, to measure private equity fair value without making subjective judgements. As a result, their fair value would not be reliable and, hence, decisionuseful. Gathering information and estimating their fair value would also be costly and, probably, would not exceed benefits. IASB has agreed that requiring fair value for all the investments in equity imposes additional costs on preparers. Nevertheless, it has claimed that "these costs are justified by improved decision-usefulness information" (IFRS 9 Exposure Draft, July 2009).

The debate on fair value measurement using valuation techniques has continued for decades. Proponents of fair value argue that it provides capital market participants with relevant information that is not readily available from other sources. They contend that fair value information has greater relevance and provides better information for making forward-looking economic decision (Barth 2006).

In contrast, critics to fair value argue that it is less verifiable by investors, subject to greater estimation errors by management and prone to greater managerial manipulation. These shortcomings create information asymmetry between investors and managers and can be a serious threat to the reliability of fair value (Watts 2003a; Watts 2003b; Landsman 2007; Penman 2007). 


\section{1 \\ Volatility in accounting data}

Valuation uncertainty related to valuation techniques is also one of the main concerns of the regulators. The Financial Stability Board - in the November 2011 Report to G20 Leaders - also recommends that standard setters require firms to adjust valuations in order to avoid overstatement of income when significant uncertainty about valuation exists.

Valuation techniques introduce estimation errors and make financial reporting more volatile. Volatility in accounting data is a relevant issue especially for banks as capital requirements are largely derived from financial report. As highlighted by Enria et al. (2004), volatility in financial reporting causes procyclical effects on capital requirements and real economy financing. Therefore, it can consistently affect public goods such as financial stability.

Barth (2004) points out that in a semi-strong form of market efficiency, volatility from period-to-period in fair values and, therefore, in financial statements derives from two sources. One is the firm's activity during the period and changes in economic conditions. This volatility, called inherent volatility, derives from economic, not accounting forces. Inherent volatility is the volatility of the asset itself.

However, there is another source of volatility, which is called estimation error volatility. Estimation error volatility is related to the fact that accountants usually do not observe the fair value of an asset and need to estimate it. Fair values obtained by valuation techniques entail estimation errors and the resulting asset volatility is attributable not only to inherent changes in economic conditions, but also to measurement errors ${ }^{1}$.

Inherent volatility relates to relevance, which is an information notion, whereas estimation error volatility relates to reliability.

Since volatility is expected to become greater as fair value inputs become less observable, we now turn our discussion to the reliability of Level 2 and Level 3 inputs to fair value measurement.

${ }^{1}$ To see these sources of volatility, consider an asset to be measured at fair value. $x$ is the fair value of the asset. The mean of $x$ is $\bar{x}$ and the variance of $x$ is $\sigma_{x}^{2}$. Thus, at any point time, the realization of $x$ is drawn from a distribution. The variance of $x$, $\sigma_{x}^{2}$, is its inherent volatility. Usually, accountants do not observe $x$ and need to estimate it. Thus, the amount recognized in the financial statements is $X=x+\varepsilon$, where $\varepsilon$ is the estimation error, which has a variance of $\sigma_{\varepsilon}^{2}$. In a simple setting, $\varepsilon$ has mean zero, which indicates that the recognized amount, $X$, is an unbiased measure of $x$. In such a setting, the estimation error, $X-x$, equals $\varepsilon$ and $\sigma_{\varepsilon}^{2}$ is the estimation error volatility of $x$. Assuming $X$ and $x$ are uncorrelated, $\sigma_{X}^{2}=\sigma_{x}^{2}+\sigma_{\varepsilon}^{2}$. Thus, the volatility of the recognized amount, $X$, is greater than the volatility of the underlying amount, $x$. 


\section{2}

\section{Fair value estimate reliability}

Reliability plays a key role when accounting standard setters evaluate possible measurement constructs. For this reason, a long-standing debate on fair value accounting has been centred on the reliability of different fair value measurements.

Information is reliable when it is free from material error and bias and can be depended upon by users to represent faithfully what it either purports to represent or could reasonably be expected to represent and is complete within the bounds of materiality and costs.

Prior research has investigated the reliability of different fair value measurements for financial assets by assessing their value relevance. The higher the reliability of accounting data, the higher their value relevance is (Barth et al. 2001).

Indeed, several studies show that fair value relevance varies according to the source of information. Petroni and Wahlen (1995), for instance, find that fair values of equities and Treasury securities are value-relevant whereas fair values of municipal and corporate bonds are not, suggesting fair values of securities actively traded in the market are considered as more reliable. Nelson (1996) documents that fair value of bank loans, deposits and long-term debt are not value-relevant. In contrast, Barth et al. (1996) find that fair values of loans are value-relevant, whereas Eccher et al. (1996) find the value relevance of loans only in limited settings. Finally, Venkatachalan (1996) examines the value relevance of derivative fair values and finds that such fair values are positively associated with equity market value.

Some papers have focused directly on the value relevance of the three level inputs in the fair value hierarchy (Kolev 2009; Goh et al. 2009; Song, Thomas and Yi 2010). They show that investors are aware of estimation errors and, therefore, value the three levels of the fair value hierarchy differently. In particular, Kolev (2009) and Goh et al. (2009) document that investors value Level 2 less than Level 1 assets but do not differentiate between Level 2 and Level 3.

\section{3}

\section{Economic consequences of estimation errors}

Estimation errors bear important economic consequences.

Archival research, for instance, document that estimation errors inherent to accounting information have a cost in terms of investors' adverse selection, liquidity risk and informationprocessing costs, all of which increase a firm's cost of capital.

Diamond and Verrecchia (1991) and Baiman and Verrecchia (1996), document that the cost of capital for firms increases as quality of information decreases. As the cost of capital increases, the value of a firm's assets decreases. In fact, investors, to the extent that they perceive greater uncertainty of accounting numbers, adjust upward the discount rate applied to the reported amount, resulting in less than a one-to-one valuation. Accounting amounts that are less reliable are assigned a higher cost of capital and, therefore, are valued less than a more reliable amount. 
Moreover, investors, to the extent that they perceive reported assets to be biased upward, adjust downward for a cash flow effect. By cash flow effect, we mean that investors perceive management estimates of future cash flows to differ systematically from realized future cash flow.

When certain accounting information is subjective in nature, and managers are allowed to exercise a degree of discretion over it, managers are more likely to generate intentional biases in their estimations (Aboody et al. 2006; Bartov et al. 2007). To the extent that these biases are expected on average, investors are likely to adjust such estimates in valuing the firm. Again, this adjustment results in less than one-to-one valuation of the reported amount.

Song, Thomas and Yi 2010 show that if investors are concerned about possible overstatement of Level 2 and Level 3 fair value assets, then they adjust their valuation of management-reported assets to less than 1 .

Less reliable accounting information also reduces the ability of investors to monitor managerial behaviour, potentially reducing the firm's operating performance and future cash flows. Many studies discuss the important role of financial accounting information as a mechanism to discipline managerial behaviour and show that as financial information quality deteriorates, investors lose their ability to link manager activities to firm performance (Bushman and Smith 2001; Lombardo and Pagano 2002; Bens and Monahan 2004; Kanodia et al. 2004; Biddle and Hilary 2006; Hope and Thomas 2008). Without the disciplining mechanism afforded by reliable financial accounting information, managers are held less accountable for their actions and therefore operate the firm less efficiently or extract private benefits directly, both of which are detrimental to firm value. Mark-to-Model fair values are less observable, making it difficult for investors to link their performance to managerial decisions and, therefore, reducing the efficiency of these activities. Hence, several doubts can be raised over the capability of mark-tomodel fair values to provide information useful to assess the stewardship of management.

Finally, as stated above, estimation errors increase volatility in accounting data. This issue is particularly relevant for banks as capital requirements are largely derived from financial reports. Volatility in accounting data leads to procyclical effects on capital requirement and, therefore, on real economy financing (Enria et al. 2004).

\section{4}

\section{Differences between private and public equity performance}

IFRS 13 states that fair value must be a market-based measurement.

Since private equities do not have a directly observable exit prices, valuation techniques must be used to assess their fair value. According to IFRS 13, Level 2 inputs - such as transaction and market multiples - must have the highest priority in valuation techniques as they are corroborated by observable market data.

Applying market multiples implies considering a set of comparable publicly traded companies. However, a certain number of studies show that the performance of private equities is relatively different from that of publicly traded companies. Quigley and Woodward (2002) and Moskowitz and Vissing-Jorgensen (2002), for instance, report lower returns for private than for 
public equity. Cochrane (2005) also documents a extraordinary skewness of returns since most returns are modest, but there is a long right tail of extraordinary good returns. In contrast, Liungqvist and Richardson (2003) document that private equity generates excess returns on the order of five to eight percent per annum relative to the aggregate public equity market.

On the other hand, Kim and Ritter (1999) examine the predictive ability of market multiples for private equity valuation. They test price-to-earnings, price-to-sales, enterprise value-to-sales and enterprise value-to-operating cash flow ratios, which are widely recommended by academics and commonly used by practitioners, and find that such ratios do a relatively poor job especially when they are based on historical numbers. Moreover, they document that relevant adjustments for differences in growth and profitability should be necessary, given the wide variation of such ratios within an industry.

\section{5}

\section{The strategic intent of private equity investments}

Using market prices could also be highly misleading as private equities are usually held with strategic intent. In almost every case, they are not held for trading but part of a long-term investment devoted to exploit business opportunities or commercial/entrepreneurial relationships, with no expectation of any capital gain.

As a consequence, fair values based on market prices could be inappropriate to represent the real values of private equity investments as they do not necessarily reflect the manner in which cash flows associated with an asset will be realized.

Ryan (2007) also points out that market-based fair values may misrepresent management intent to hold an asset. Investors are aware of that and, in fact, Koonce et al. (2011) document investors' reluctance to embrace fair values for items not to be sold soon.

As pointed out by Whittington (2008), fair value should instead reflect the opportunities related to the investment actually available to the reporting entity and entity-specific assumptions should also be made. The Financial Stability Board, which shares such a view, in its July 2010 Report to G20 Leaders claims that "while reaffirming the framework of fair value accounting, we have agreed that the accounting standards setters should improve standards for the valuation of financial instruments based on their liquidity and investor's holding horizons".

Actually, private equities held with a strategic intent are closer to subordinated credits rather than to equity ownership. The Basel Committee (2001) discusses such an issue and reaches the same conclusion. As a consequence, it allows banks which use recognized a internal rating based approach to use an alternative method for regulatory capital calculation, called PD/LGD, for equity investments - even if public - that are part of a long-term customer relationship in which returns on investment are based on regular and periodic cash flows not derived from capital gains and where there is no expectation of future capital gain or of realising any existing gain in the 
long term ${ }^{2}$. In most cases, the estimated probability of default is readily available as the financial institution has also lending and/or general banking relationships with the portfolio company.

\section{4. OUR FIELD-TEST}

The purpose of this field-study is to add some specific empirical evidence to our discussion. Differently from prior studies, which test fair value measurements indirectly by using their value relevance as a proxy for reliability, we assess fair value reliability directly by comparing fair values obtained by valuation techniques with real market prices. In fact, consistently with IFRS 13 , we assume that quoted prices in active market provide the most reliable fair value.

We form a portfolio of listed companies which we assume to be private and we evaluate according to IFRS 13 . We assume to hold these investments over a period of 5 years, from the beginning of 2006 to the end of 2010, and we set up an equally weighted portfolio at the starting date. We focus on the financial market crisis which started in 2007 since during periods of turmoil stakeholders seek for higher financial information quality, which, on the contrary, is difficult for firms to guarantee.

We evaluate our portfolio equities by using three techniques - transaction multiples, market multiples and option approach - and we compare the results with one another as well as with market capitalization and book value at the same measurement date. The valuation techniques we apply are based on inputs categorized within Level 2 of the fair value hierarchy established by IFRS 13. Hence, they can be considered as equally desirable alternatives. Moreover, Level 2 inputs are corroborated by observable market data and, therefore, IFRS 13 consider them highly unbiased. Finally, we use book value as a proxy for the equity method of accounting prescribed by IAS 28.

In order to understand whether and how much valuation technique measurements result in reliable fair values, we compare fair values obtained by valuation techniques with the 'real' market price at the measurement date. We use market price in order to test the capability of valuation techniques to provide a faithful representation of the real-world economic phenomena they purport to represent.

2 The Basel Committee, in its Working Paper on Risk Sensitive Approach for Equity Exposure in the Banking Book for IRB Banks (2001), details a definition of private equities held with strategic intent which includes the following:

a) Direct Holdings - Holdings in securities, and other financial assets whose principal values are directly related to the value of ownership interests in a commercial endeavour, whether voting or non-voting, that convey a residual interest in the assets and income of the enterprise.

b) Indirect Holdings and Fund Investments - Holdings in a corporation, partnership, limited liability company or other type of enterprise (including any form of special purpose vehicle) that issues ownership interests and is engaged in the business of investing in the instruments defined above.

c) Residual Interests - Holdings in residual ownership interests of commercial enterprises that allow the enterprise to waive or defer interest or other contractual remuneration to the holder, such as perpetual preferred shares.

d) Any security (other than convertible bonds) that ranks pari passu in liquidation with any element included in (a), (b) or (c) above. 
Obviously, we are perfectly aware that different valuation techniques produce different fair value estimates. However, our focus is on their implications for financial reporting reliability and comparability.

In our field-test, we also apply an option approach. The option approach could suit well the case of private equities held with a strategic intent and, for this reason, we test its performance.

As outlined by Cochrane (2005), the strategic intent can be read as an option for the holding company on the future return of a venture whose value is embedded in business related operations and/or entrepreneurial relationships. Thus, an option approach allows for the incorporating into fair values of the economic scope and the actual opportunities underlying the specific investments which, however, would be taken into consideration by market participants.

Moreover, the option approach allows for dealing well with highly uncertain environment and times - such as the ones we are currently experiencing - and for this reason we believe that it deserves renewed consideration.

Similarly to Brockman and Turtle (2003), in applying an option approach, we follow the suggestion offered by Merton in his seminal article (1974) and we use the financial distress of a firm as a clear and strong barrier. In such a framework, the intent of the holding is that of permanently staying in a business unless the subsidiary's financial structure falls into financial distress, that is the cumulated debt amount is meaningfully higher than the asset value.

An option approach which uses firm insolvency as a strike price can easily be implemented, especially by banks, due to internal rating diffusion, third party evaluations and advanced simulation tools. The option approach we apply is compliant with IFRS 13 and involves Level 2 inputs such as credit risk and risk premium, which are directly observable and do not require any adjustment. The Appendix provides details about the option approach we apply.

\section{1 \\ Sample and data}

In our field-test, we focus on European non-financial firms operating in high investmentintensive or cyclical industries such as chemicals, energy, aerospace and defence, technology, automobiles, telecom, healthcare, natural resources, homebuilding and related sectors. The high level of risk related to their business makes them particularly suitable for an option approach valuation.

The sample is randomly selected and includes the following firms: Finmeccanica, SanofiAventis, Eni, Fiat, Edf, Iberdrola, Upm, Rhodia, Clariant, Telefonica, Nokia, Sap, Volkswagen, Telecom, HeidelbergCement, Xstrata, Statoil, SaintGobain, Bayer and Storaenso.

For each sample firm we compute equity fair value according to market multiples, transaction multiples and the option approach over the 2006-2010 period. The total observations are 120 . We then compute profits and losses - in absolute and relative values - for each firm over the same period and the observations are 100. Data on market capitalization are obtained by Datastream. Market multiples and transaction multiples are obtained from Fitch Ratings and are based on historical earning figures. We select multiples which closely match the characteristics of our sample firms. 
We implement valuation models consistently with best practice. The market and the transaction multiples are applied to the EV/EBITDA margin and the equity fair value is obtained by subtracting the net financial debt from - or summing the net cash and cash equivalent to - the enterprise value. Transaction multiples used in this paper are a mean between transaction multiples relative to the measurement year and the previous year. Moreover, we make the assumption that a $35 \%$ majority premium has been incorporated into transaction prices.

Accounting figures (EBITDA, Book Value, Net Financial Position) are extracted from companies' financial reportings and standardised on common criteria basis.

In order to perform the option approach, we assume that the rating assigned by the official agencies is fair and reflects the actual expected default probability for the rated company. We use official ratings assigned by Standard and Poor's.

Following a Merton approach, asset values, asset volatility and, finally, equity fair value are computed. Details about the option valuation methodology we apply can be found in the appendix.

Rating agencies' actual default rate is 'real world', whereas the Black-Scholes-Merton formula is valid in a 'risk neutral' world. The risk premium needed to reconcile the two measures is extracted from the market expected Earning to Price ratios observed at the measurement date on the European stock market by using IBES forecasts. Interest rates at the measurement dates are obtained from Datastream.

\section{2. \\ Results}

The valuation techniques applied in order to assess our portfolio fair values provide very different results. Differences are relevant not only among the valuation techniques but also if compared with the actual values.

(Please insert Table 1 about here)

As results from Table 1, fair values based on market multiples and transaction multiples outperform, on average, actual values given by market capitalization. Market multiples double actual values $(+118.3$ percent) in mean and are 37.2 percent higher in median, whereas transaction multiples outperform market capitalization by 63.2 percent in mean and 22.6 percent in median. Moreover, market multiple values are, on average, more than 4 times the book value, transaction multiple values more than 3 times while market capitalization is only twice.

Differences between transaction multiples and actual values can be explained by the fact that transaction multiples include only successful transactions and incorporate synergy expectations as well as other positive factors taken into account by the buyers, which contribute to the increase in transaction prices. As such, they include some entity-specific measurement, whereas according to IFRS 13 - fair value should be a truly market-based measurement.

Differences between market multiples and actual values, instead, are attributable to the fact that market multiples are computed on a certain number of firm comparables. As a result, market multiples provide the same effect of portfolio diversification and elide the idiosyncratic 
component of risk. The lower the risk is the higher the fair value is, too. Our findings on market multiples are consistent with those of Kim and Ritter (1999).

We also apply statistical tests in order to draw inference from our results. The Wilcoxon and the $t$-test indicate that differences between market and transaction multiples, on the one hand, and market capitalization, on the other hand, are statistically significant at 0.01 level (two-tail test).

Hence, statistical analysis supports our claim that market and transaction multiples do a poor job as they provide fair values which are not a faithful representation of the real-world economic phenomena they purport to represent. Many firm-specific factors are not captured by comparable multiples unless various adjustments for differences in growth and profitability are made.

Market and transaction multiples also show a higher volatility, compared to market capitalization, which makes fair value estimates fluctuate more than firms' fundamentals would suggest. Standard deviation related to transaction multiples doubles the actual one, while volatility related to market multiples is even more than three times higher. Such findings prove that, on the one hand, transaction and market multiples are highly time and cycle- specific. On the other hand, fair value based on them entails high estimation errors.

The option approach shows, on average, a higher mean (+8.8 percent) and a lower median (23.4 percent) compared to market capitalization. However, such differences are not statistically supported at the conventional levels used in economic research. From an economic perspective, they can suggest that fair values based on the option approach are less biased, with respect to actual values, than transaction and market multiples.

Table 2 provides Pearson's correlation coefficients between fair values based on market multiples, transaction multiples and the option approach, on the one hand, and market capitalization and book value, on the other hand.

(Please insert Table 2 about here)

All the three valuation techniques show a high and statistically significant correlation both with book value and market capitalization. However, market and transaction multiples show a slightly stronger correlation with market capitalization, while the option approach has a stronger correlation with book value.

A stronger correlation between market multiples and market capitalization is expected given that market multiples capture non-diversifiable risk factors which affect, at the same time, our portfolio value as well as that of their comparables. Transaction multiples, instead, show a lower correlation with actual values, coherently with the fact that they are based on past transactions and, therefore, lag market price development. As a result, they are likely to be biased in their capability to estimate an actual exit price.

Fair values based on the option approach have a stronger correlation with book value than with market capitalization. In fact, under the option approach, capital inflow is critical to the investor in order to decide whether to abandon a certain investment.

Tables 3 to 5 display our portfolio fair values per year. The first two columns (from left) are portfolio references and report book values and actual values, respectively. The remaining three columns display the results of the different valuation techniques used to assess portfolio fair values. 
Table 3 displays the portfolio fair values as they would be reported in the balance sheet, at the end of each financial year, under transaction multiples, market multiples and the option approach. Figure 1 depicts our portfolio values and their polynomial interpolation.

(Please insert Table 3 about here)

Differences in our portfolio values after five years are astonishing. In each reporting year, our portfolio fair value estimates outperform the current market prices and none of them reflects the severity of the financial market crisis. While market capitalization has reduced by 20.6 percent since 2006, our portfolio value has increased by 26 percent under the market multiples, by 7.8 percent under the transaction multiples and by 68.7 percent under the option approach.

Our portfolio actual value has quoted below its book value since 2008. At the end of 2010, its actual value is 36.9 percent lower than its book value.

In contrast, at the same date, portfolio fair values under market multiples and transaction multiples are nearly the same and they outperform book value by 19.1 percent in the case of market multiples and by 17.1 percent in the case of transaction multiples. Moreover, our portfolio fair value is 88.6 percent higher than its actual value under market multiples and 85.4 percent higher under transaction multiples.

As stated above, such a result is not surprising for market multiples, which tend to elide idiosyncratic risk.

Transaction multiples, instead, are case of revealed preferences as they refer only to successful transactions and include synergy expectations as well as other positive factors taken into account by the buyers, which contribute to the increase of transaction prices.

Differently from the other valuation techniques, the option approach provides portfolio fair values that are less exposed to market cycle. Apart from 2008, portfolio values have steadily increased over the holding period. At the end of 2010, the portfolio fair value is 2.5 times its actual value, 1.6 times its book value and also outperforms market multiples as well as transaction multiples. Moreover, on average, fair values under the option approach are higher than the market multiples, the actual values and the book values and nearly the same as transaction multiples. Such results are consistent with the fact that, in option pricing, volatility implies not only possible future losses, but also potential gains. Hence, volatility is a value and is positively correlated with equity value.

Table 3 also indicates that standard deviation under the transaction multiples, the market multiples and the option approach is higher than the actual one. Hence, using valuation techniques, our portfolio would be reported in the balance sheet at higher and much more volatile values than the actual ones. Standard deviation is 1.26 times the actual one under the market multiples, 2.26 times under the transaction multiples and 2.29 times under the option approach. As outlined by Barth (2004), standard deviation differences between valuation techniques and actual values are good proxies for portfolio measurement errors.

(Please insert Figure 1 about here)

One of the main concerns for management and shareholders is also in the financial year income statement. Investment choices, value creation and management compensation are based on profit and loss analysis and result comparisons. Therefore, assessing the impact of different valuation techniques on profit and loss account is key to assessing their reliability and suitability. 
Table 4 displays portfolio profits and losses per year as they would be reported in the income statement.

(Please insert Table 4 about here)

Income statement based on valuation techniques would report, on average, a value creation which the actual values do not. On average, market multiples, transaction multiples, the option approach and book value show a profit, whereas actual values report a loss. Moreover, portfolio profits and losses computed using transaction multiples - which are by nature time and cyclespecific - show a higher volatility and, therefore, lead to a more swinging value creation than actual values.

The average profit of 66.82 under transaction multiples is, however, the lowest of the three valuation techniques. Such a result could be explained by the fact that transaction prices are usually based on cash flow present value techniques in which volatility is considered only in terms of potential future losses, implies a higher expected return, a lower equity value and, as a result, a lower value creation.

Conversely, our portfolio value computed under the option approach reflects the volatility of the market environment more than falling market prices. In option pricing, volatility is a value and, in fact, our portfolio shows an average value creation of 515.45, the highest amount among valuation techniques.

\section{(Please insert Figure 2 about here)}

The same conclusions could be drawn by observing portfolio returns over the holding period.

(Please insert Table 5 and Figure 3 about here)

As shown in Table 5, shareholders would observe a portfolio return which is, on average, 10 times the actual one under the transaction multiples; more than 3 times under the market multiples and more than 5 times under the option approach. Also portfolio return based on book value is, on average, more than twice the actual one.

However, in 2008 all the portfolio returns, including those computed on book value, are negative. In 2009 market capitalization shows a recovery, while transaction multiples still report a negative return, consistently with the fact that they lag market development. At the same date, the portfolio return under market multiples is slightly negative, which is consistent with the fact that market multiples tend to elide the idiosyncratic component of risk.

Moreover, portfolio returns based on transaction multiples show the highest volatility, which could mislead shareholder appraisal of management effectiveness.

Finally, Table 6 and Figure 4 display the portfolio price-to-book value ratios per each year.

(Please insert Table 6 and Figure 4 about here)

Differences among valuation techniques and between valuation techniques and actual values are really outstanding. None of the valuation techniques reflects the portfolio actual losses incurred during the crisis. Just in 2009 transaction multiples indicate a loss compared to portfolio book value, whereas market multiples and the option approach still show value creation. 


\section{5. CONCLUSIONS}

In this paper, we discuss the potential economic consequences of IFRS 13 endorsement in the European Union. Our focus is on private equity valuation.

We review prior research and perform a field-test in order to shed light on the possible effects of its adoption.

IFRS 13 states that fair value must be a market-based measurement and the firm's intention to hold the asset is irrelevant.

We discuss such a definition and claim that, in almost any case, private equities are not held for trading purposes as they are part of long term investments devoted to exploit particular business opportunities, with no expectation of any future capital gain. A market-based, rather than an entity-specific, fair value measurement fails to consider both the financial instrument liquidity and investors' holding horizons which, instead, are key to private equity valuation. As such, a market-based fair value measurement would deter financial statement preparers from analyzing the relevant underlying parameters for their valuation.

Moreover, we document that the historical performance of private equities is relatively different from publicly traded companies. Therefore, market prices cannot be predictive of private equity fair values, especially when private equities are held with a strategic intent and not for capital gain purpose.

In our field-test, we show that market-based valuation techniques fail to provide fair values which are a faithful representation of the economic real world phenomena they purport to represent. Consistently with previous research, we show that market and transaction multiples do a poor job and relevant entity-specific adjustments for differences in growth and profitability will be necessary.

Our findings document that transaction multiples provide the highest fair values, coherently with the fact that they are case of 'revealed preferences'. In fact, such multiples refer only to successful transactions and incorporate synergy expectations as well as other positive factors which increase transaction prices.

Market multiples, instead, are average values which elide the idiosyncratic component of risk.

Transaction and market multiples also lead to highly volatile fair values, thus proving that market-based techniques are largely affected by the economic cycle as well as by market trends, which amplify effects and value appraisals.

In our paper, we also test an option approach which could well suit private equities held with strategic intent given that the strategic intent can be read as an option whose value is embedded in a business opportunity.

The option approach has critical elements related to the extreme sensitivity of some parameters such as corporate assets volatility, which need to be derived from other inputs. However, thanks to internal rating diffusion, third party evaluations and advanced simulation tools, it could provide holding companies, especially banks, with an effective support to private equity valuation. 
Under the option approach, fair values show a stronger correlation with book values rather than with actual values, thus proving to be less cycle and market trend-dependent. Moreover, fair values are higher than under the transaction and market multiples, consistently with the fact that, in option pricing, volatility is a value and implies not only possible future losses but also potential gains. As a result, over the holding period, our portfolio fair value has steadily increased following the book value path.

In conclusion, our findings show that assessing private equity fair values using market-based valuation techniques misleads performance analysis and appraisals as well as management choices and compensation and it also alters comparison among financial reports. Value creation largely varies depending on the selected valuation technique.

Such evidence is particularly relevant for market and transaction multiples as they should be highly unbiased and, therefore, categorised by IFRS 13 within Level 2 inputs of the fair value hierarchy.

As a matter of fact, our paper questions whether IFRS 13 fair value definition is able to effectively enhance transparency and comparability of accounting data, especially when private equities are not held for trading purposes.

Evidence on this point is of direct interest to accounting policy makers since the explicit purpose of the European Union Regulation 1606/2002, which has introduced the IAS/IFRS accounting system in the European Union, is to ensure a high degree of transparency and comparability in financial statements as well as the efficient functioning of the capital market.

The IASB Framework also states that fair value accounting is expected to provide investors with useful information to predict the capacity of firms to generate cash flow from their assets.

Finally, we show that estimation errors bear important economic consequences. They increase volatility in accounting data, which - in turn - have important effects on bank capital requirements and real economy financing. For this reason, we believe that the real capability of IFRS 13 to conduce to the European public good should be further investigated. 


\section{APPENDIX: \\ THE OPTION VALUATION METHODOLOGY}

As mentioned above, the option valuation method adopted in this paper follows a Merton approach. The holding's intent is read as the opportunity to permanently stay in the business unless the subsidiary financial structure is falling in financial distress, which means that it is not going to default because of a cumulated debt amount significantly higher than subsidiary assets value.

In this perspective, let us assume that the subsidiary asset value $\left(\mathrm{A}_{\mathrm{i}}\right)$ follows a stochastic Wiener diffusion process described in this way:

$$
d A_{i}=\mu_{i} A_{i} d t+\sigma_{i} A_{i} d x_{i}
$$

in which

$A_{i}$ is the enterprise value and $t$ is the time span to the expiration date of the option barrier $B^{3}$,

$\mathrm{X}_{\mathrm{i}}$ is a stochastic normally distributed standardized variable $(\mathrm{Z})$ that perturbs the asset value $\mathrm{A}_{\mathrm{i}}$ with volatility $\sigma_{i}$.

The enterprise value $A_{i}$ at $T$ may be written as:

$$
\log A_{i}(T)=\log A_{i}+\mu_{i} T-\frac{\sigma_{i}^{2} T}{2}+\sigma_{i} \sqrt{T} X_{i}
$$

Based on the Merton's option approach, the probability to breach the debt barrier at debt maturity is:

$$
p_{\operatorname{def}_{i}}=P\left[A_{i}(T)\left\langle B_{i}\right]=P\left[X_{i}\left\langle c_{i}\right]=N\left(c_{i}\right)\right.\right.
$$

where $c_{\mathrm{i}}$ is the financial distress threshold (liquidation point), defined as ${ }^{4}$ :

$$
c_{i}=\frac{\log B_{i}-\log A_{i}-\mu_{i} T+\frac{\sigma_{i}^{2} T}{2}}{\sigma_{i} \sqrt{T}}
$$

and $N$ is the cumulative normal distribution operator.

In the Merton approach $c_{i}$ is the unknown, dependent variable. In our application we suppose to have an external assessment of $c_{i}$, usually defined as probability of default, very often denoted as PD. Such assessment could be derived from rating agencies' public rating class or could derive

\footnotetext{
${ }^{3}$ In a Merton approach this barrier is the outstanding debt at the expiration date T. Hence B is the outstanding debt at that date. In our approach is the holding's liquidation point.

${ }^{4}$ For the sake of simplicity dividend payment is considered as negligible.
} 
from the application of banking internal rating models 5 . These PDs are usually referred to "real world" frequencies, which means that they are based on observed default rates over a pre-set period, usually 12 months.

Combining the equations defined before, $\mathrm{PD}$ formulation in the real world is:

$$
P D=N\left(\frac{\ln (B)-\ln \left(A_{i}\right)-\mu T+1 / 2 \sigma_{A}^{2} T}{\sigma_{A} \sqrt{T}}\right)
$$

in which $\ln$ is the natural logarithm, B is the debt face value, Ai is the firm's asset value (equal to the market value of equity and debt, net of available cash and equivalents), ${ }^{\mu}$ is the expected return, $\mathrm{T}$ is the remaining time to overall debt maturity, $\sigma \mathrm{a}$ is the instantaneous assets value volatility (standard deviation); $\mathrm{N}$ is the cumulated normal distribution operator.

It is worth noting that the Black-Scholes-Merton (BSM) formula is valid in a so called "risk neutral approach" (see Vasicek, 1984). Hence the solution needs risk neutral probabilities. Here we have real world default probability, which means the default frequencies observed among public rated bond issuers. To pass from actual to risk neutral default probabilities, a calculation is needed. Let us define the value of a credit contract as:

$$
V_{F}=C_{0} e^{-r t}\left(1-q_{t} w\right)
$$

in which

$\mathrm{V}=$ credit market value of contract of $\mathrm{F}$ face value,

$\mathrm{C}_{\mathrm{t}}=$ initial credit face value

$w=$ loss given default

Using Black-Scholes-Merton formula, we can define

q risk neutral world $=\mathrm{N}(-\mathrm{Z})$

p real world $=\mathrm{N}\left(-Z^{1}\right)$

in which

$$
Z=\frac{\left[\ln \left(\frac{V}{D}\right)+r_{\text {riskfreee }}-\frac{\sigma_{v}^{2}}{2}\right]}{\sigma_{v}}
$$

\footnotetext{
5 This second source is spreading across the world because of the new banking regulation that recognizes internal rating for regulatory capital purposes.
} 


$$
Z^{1}=\frac{\left[\ln \left(\frac{V}{D}\right)+r_{\text {riskyworld }}-\frac{\sigma_{v}^{2}}{2}\right]}{\sigma_{v}}
$$

so

$$
q=N\left\{N^{-1}(p)+\frac{r_{\text {riskyworld }}-r_{\text {riskfree }}}{\sigma_{v}}\right\}
$$

Having an assessment of the PD, F is known and $\mu$ is exogenously set using market data. For our purposes, market risk premium for a risk averse investment in the economy is set as the Earning-to-Price value less the risk free rate. Earning-to-price ratio is extracted from I/BE/S 12 month forecasts (source: Thomson Reuters Datastream) on the Eurostoxx market.

Then, we forced the BSM formula to generate the available rating agency's implied PD, simultaneously moving $\mathrm{T}$ and $\sigma_{\mathrm{v}}$. In particular $\mathrm{T}$ is set at the minimum level to reach a feasible solution in the real world (if less than 1 is set to 1); asset value volatility is then iteratively extracted to reach the solution. In this way we reach an assessment of assets value. Equity value is then extracted as

$$
E=V \cdot N\left(d_{1}\right)-D e^{-i T} N\left(d_{2}\right)
$$

in which:

$$
\begin{aligned}
& d_{1}=\frac{\left\{\ln \left(\frac{V}{D}\right)+\left(\mu+\frac{\sigma_{v}^{2}}{2}\right) T\right\}}{\sigma_{v} \sqrt{T}} \\
& d_{2}=d_{1}-\sigma_{v} \sqrt{T}
\end{aligned}
$$

In this way we obtain an equity value consistent with the rating implied PD, based on outstanding debt, time horizon, expected return and business risk (i.e. assets value volatility).

It is worth noting that the option approach differs from the usual discounted cash flow valuation method (DCF), in particular due to the crucial role of volatility. In the DCF method increasing volatility implies a reduction of value, all being equal, because it improves the risk adjusted discount rate. In real option method instead the higher the volatility is, the higher the value is because it implies potential larger future opportunities, not only risks. At the same time longer time horizons and higher risk free rates enhance real option values while they negatively impact on DCF values. That is to say that by applying different valuation methodologies, despite the fact that these are based on the same market observations, according to the different methods' assumptions we reach opposite impacts on final values and, therefore, on showed returns and performances. 


\section{References}

ABOODY D., BARTH M.E., KASZNIK R. (2006) “Do firms understate stock option-based compensation expense disclosed under FAS 123?”, Review of Accounting Studies, 11 (4): 429-461.

BAIMAN S., VERRECCHIA R. (1996) "The relation among capital markets, financial disclosure, production efficiency, and insider trading", Journal of Accounting Research, 34 (1): 1-22.

BARRY C.B., BROWN S.J. (1985) "Differential Information and Security Market Equilibrium", Journal of Financial and Quantitative Analysis, 20 (4): 407-422.

BARRY C.B., BROWN S.J. (1986) "Limited Information as a Source of Risk", Journal of Portfolio Management, Winter: 66-72.

BARTH M.E. (2004) "Fair Values and Financial Statement Volatility", in: Claudio Borio et al. (eds) The Market Discipline Across Countries and Industries, (MIT Press, Cambridge).

BARTH M.E. (1994) "Fair Value Accounting: Evidence from Investment Securities and the Market Valuation of Banks", The Accounting Review, 69 (1): 1-25.

BARTH M.E., BEAVER W.H., LANDSMAN W.R. ( 1996), "Value-relevance of banks' fair value disclosures under FAS No. 107”, The Accounting Review, 71 (4): 513-537.

BARTH M.E., BEAVER W.H., LANDSMAN W.R. (2001) "The relevance of the value relevance literature for accounting standard-setting: Another view", Journal of Accounting and Economics, 31 (1-3): 77-104.

BARTH M.E., CLINCH G., SHIBANO T. (2003) "Market Effects of Recognition and Disclosure", Journal of Accounting Research, 41 (4): 581-609.

BARTH M.E. (2006) "Including Estimates of the Future in Today's Financial Statements", Accounting Horizons, 20 (3): $271-285$.

BARTOV E., MOHANRAM P., NISSIM D. (2007) "Managerial discretion and the economic determinations of the disclosed volatility parameter for valuing ESOs", Review of Accounting Studies, 12 (1): $155-179$.

BASEL COMMITTEE ON BANKING SUPERVISION (2001) Risk Sensitive Approaches for Equity Exposures in the Banking Book for IRB Banks, Working paper, Bank of International Settlements.

BASEL COMMITTEE ON BANKING SUPERVISION (2009) Guiding principles for the replacement of IAS 39, Working paper, Bank of International Settlements.

BENS D.A., MONAHAN S.J. (2004) "Disclosure quality and the excess value of diversification", Journal of Accounting Research, 42 (4): 691-730.

BIDDLE G., HILARY G. (2006) “Accounting quality and firm-level capital investment”, The Accounting Review, 81 (5): 963-982.

BLOOMFIELD R.J., NELSON M.W., SMITH S.D. (2004) Investing in Your Own Equity: Effects of Fair Value Accounting and Comprehensive Income Recognition on Earnings and Price Volatility, Unpublished paper.

BROCKMAN P., TURTLE H.J. (2003) “A barrier option framework for corporate security valuation”, Journal of Financial Economics 67, (3): 511-529.

BROMWICH M. (2004) "Aspects of the Future in Accounting: The Use of Market Prices and "Fair Values" in Financial Reports", in: C. Leuz, D. Pfaff, A. Hopwood (eds) The Economics and Politics of Accounting, (University Press, Oxford).

BUSHMAN R.M., SMITH A.J. (2001) "Financial Accounting information and corporate governance", Journal of Accounting and Economics, 32 (1-3): 237-333.

COCHRANE J.H. (2005) "The Risk and Return of Venture Capital", Journal of Financial Economics, 75 (1): 3-52

COURTNEY H., KIRKLAND J., VIGUERIE P. (1997) "Strategy under Uncertainty", Harvard Business Review.

DIAMOND D.W., VERRECCHIA R.E., (1991) "Disclosure, liquidity, and the cost of capital", The Journal of Finance, 46 (4): 1325-1359.

DIXIT K.A., PINDYCK S. (1994) Investment under Uncertainty (Princeton University Press).

DE LAURENTIS G., MAINO R., MOLTENI L. (2010) Developing, Validating and Using Internal Ratings: Methodologies and Case Studies (John Wiley \& Sons). 
ENRIA A., CAPPIELLO L., DIERICK F., GRITTINI S., HARALAMBOUS A., MADDALONI A., MOLITOR P.A.M., PIRES F., POLONI P. (2004) Fair Value Accounting and Financial Stability, Occasional Paper No. 13, European Central Bank.

FINANCIAL STABILITY BOARD, Report to G20 Leaders, July 2010.

FINANCIAL STABILITY BOARD, Report to G20 Leaders, 4 November 2011.

GOH B., NG J., YONG K. (2009) Market pricing of banks' fair value assets reported under SFAS 157 during the 2008 economic crisis, Working paper, Singapore Management University.

GOMPERS P., LERNER J. (1997) "Risk and Reward in Private Equity Investments: the Challenge of Performance Assessment", Journal of Private Equity, 1 (2): 5-12.

HITZ, J.M. (2007) "The Decision Usefulness of Fair Value Accounting-a Theoretical Perspective", European Accounting Review, 16 (2): 323-362.

HOPE O.-K., THOMAS W.B. (2008) "Managerial empire building and firm disclosure", Journal of Accounting Research, 46 (3): 591-626.

KANODIA C., SAPRA H., VENUGOPALAN R. (2004) "Should intangibles be measured: What are the economic trade-offs?", Journal of Accounting Research, 42 (1): 89-120.

KAPLAN S., SCHOAR A. (2005) "Private Equity Performance: Returns, Persistence and Capital Flows", Journal of Finance, 60 (4): 1791-1823.

KIM M., RITTER J.R. (1999) "Valuing IPOs", Journal of Financial Economics, 53 (3): 409-437.

KOLEV K. (2009) Do investors perceive marking-to-model as marking-to-myth? Early evidence from FAS No. 157 disclosure. Working paper, New York University.

KOONCE L., NELSON K.K., SHAKESPEARE C.M. (2011) "Judging the Relevance of Fair Value for Financial Instruments", The Accounting Review, 86 (6): 2075-2098.

LANDSMAN W.R. (2007) "Is fair value accounting information relevant and reliable? Evidence from capital market research", Accounting and Business Research, Special Issue: International Accounting Policy Forum:, 19-30.

LJUNGQVIST, A., RICHARDSON, M. (2003) The Cash Flow, Return and Risk Characteristics of Private Equity, New York University, Finance Working Paper No 03-001.

LOMBARDO D.,PAGANO M.(2002) "Law and equity markets: A simple model, in Renneboog, L., J McCahery, P. Moerland, and T. Raaijmakers"(eds) Corporate Governance Regimes: Convergence and Diversity (Oxford University Press).

MERTON R. (1974) “On the pricing of Corporate Debt: the Risk Structure of Interest Rates”, Journal of Finance, 29 (2): 449-470.

MILBURN J.A. (2008) "The Relationship between Fair Value, Market Value, and Efficient Markets", Accounting Perspective, 7(4): 293-316.

MOSKOWITZ T., VISSING-JORGENSEN A. (2002) "The returns to entrepreneurial investment: A private equity premium puzzle?", American Economic Review, 92: 745-778.

NELSON K. (1996) "Fair value accounting for commercial banks: An empirical analysis of FAS No. 107", The Accounting Review, 71 (2): 161-182.

PENMAN S. (2007) "Financial Reporting Quality: Is Fair Value a Plus or a Minus?", Accounting and Business Research. International Accounting Policy Forum, Special Issue 4: 33-44.

PETRONI K., WAHLEN J.M. (1995) "Fair values of equity and debt securities and share prices of property-liability insurer", The Journal of Risk and Insurance, 62 (4): 719-737.

QUIGLEY J.M., WOODWARD S.E. (2002) Private equity before the crash: Estimation of an index, Unpublished working paper, University of California at Berkeley.

RYAN S.G. (2007) Financial Instruments \& Institutions: Accounting and Disclosure Rules (John Wiley \& Sons, Inc, Hoboken, N.J.).

SONG C.J., THOMAS W.B., YI H. (2010) "Value Relevance of FAS No. 157 Fair Value Hierarchy Information and the Impact of Corporate Governance Mechanisms", The Accounting Review, 85 (4): 1375-1410.

VASICEK O. (1999). Credit Valuation. KMV, San Francisco.

VASICEK O. (2007). Loan Portfolio Value. Risk. July.

VENKATACHALAM M. (1996) "Value relevance of banks' derivatives disclosures", Journal of Accounting and Economics, 38 (2): 387-418.

VENTURE ECONOMICS (2002), Investment Benchmarks Report. Newark, NJ. 
WATTS R.L. (2003a) "Conservatism in Accounting Part I: Explanations and Implications", Accounting Horizons, 17 (3): 207-221.

WATTS R.L. (2003b) "Conservatism in Accounting Part II: Evidence and Research Opportunities", Accounting Horizons, 17 (4): 287-301.

WHITTINGTON G. (2008) "Fair Value and the IASB/FASB Conceptual Framework Project: an Different View”, Abacus, 44 (2): 139-168. 
Table 1

Asset Fair Values

\begin{tabular}{|l|c|c|c|c|c|}
\hline & Book Value & $\begin{array}{c}\text { Market } \\
\text { Capitalization }\end{array}$ & $\begin{array}{c}\text { Market } \\
\text { Multiples }\end{array}$ & $\begin{array}{c}\text { Transaction } \\
\text { Multiples }\end{array}$ & $\begin{array}{c}\text { Option } \\
\text { Approach }\end{array}$ \\
\hline Mean & $25,748^{* * *}$ & 52,930 & $115,541 * * *$ & $86,397 * * *$ & 57,574 \\
\hline Median & $14,436 * * *$ & 27,082 & $37,160 * * *$ & $33,192 * * *$ & 20,748 \\
\hline Standard Deviation & $38,481 * * *$ & 89,593 & $275,442 * * *$ & $196,037 * * *$ & $109,348 * * *$ \\
\hline Minimum & -719 & 455 & 981 & 2,365 & -698 \\
\hline Maximum & 226,000 & 538,881 & $1,679,400$ & $1,303,510$ & 604,170 \\
\hline 25 percentile & 7,156 & 8,112 & 11,283 & 9,166 & 10,657 \\
\hline 75 percentile & 27,298 & 62,575 & 97,776 & 69,226 & 46,747 \\
\hline Asimmetry & 3.75 & 3.63 & 4.39 & 4.40 & 3.72 \\
\hline Kurtosis & 15.24 & 13.96 & 19.94 & 20.35 & 14.58 \\
\hline Observations & 120 & 120 & 120 & 120 & 120 \\
\hline
\end{tabular}

*** Differences with Market Capitalization are statistically significant at 0,01 level (two tails)

Table 2

Asset Value Correlations

\begin{tabular}{|c|c|c|c|}
\hline & Market Multiples & Transaction Multiples & Option Approach \\
\hline Book Value & $0.944 * * *$ & $0.935 * * *$ & $0.969 * * *$ \\
\hline Market Capitalization & $0.974 * * *$ & $0.939 * * *$ & $0.915 * * *$ \\
\hline Observations & 120 & 120 & 120 \\
\hline
\end{tabular}

***Correlation coefficients are statistically significant at 0,01 level (two tails) 
Table 3

Portfolio fair values ( $€$, equally weighted at 2006 year beginning)

\begin{tabular}{|c|c|c|c|c|c|}
\hline $\begin{array}{c}\text { End of financial } \\
\text { year report: }\end{array}$ & Book Value & $\begin{array}{c}\text { Market } \\
\text { Capitalization }\end{array}$ & Market Multiples & $\begin{array}{c}\text { Transaction } \\
\text { Multiples }\end{array}$ & Option Approach \\
\hline 2005 & 2,000 & 2,000 & 2,000 & 2,000 & 2,000 \\
\hline 2006 & $2,301.27$ & $2,518.41$ & $2,991.72$ & $3,439.80$ & $2,997.28$ \\
\hline 2007 & $2,729.68$ & $2,972.09$ & $3,645.59$ & $5,260.64$ & $3,361.47$ \\
\hline 2008 & $2,703.16$ & $1,567.72$ & $3,243.71$ & $4,204.96$ & $3,192.51$ \\
\hline 2009 & $2,906.60$ & $1,911.49$ & $3,193.96$ & $2,759.64$ & $4,729.47$ \\
\hline 2010 & $3,165.95$ & $1,999.00$ & $3,770.18$ & $3,707.07$ & $5,059.09$ \\
\hline Mean & $2,634.44$ & $2,161.45$ & $3,140.86$ & $3,562.02$ & $3,556.64$ \\
\hline Standard deviation & 420.45 & 500.40 & 630.56 & $1,132.99$ & $1,143.64$ \\
\hline
\end{tabular}

Figure 1

Portfolio fair values, current market values and polynomial interpolation

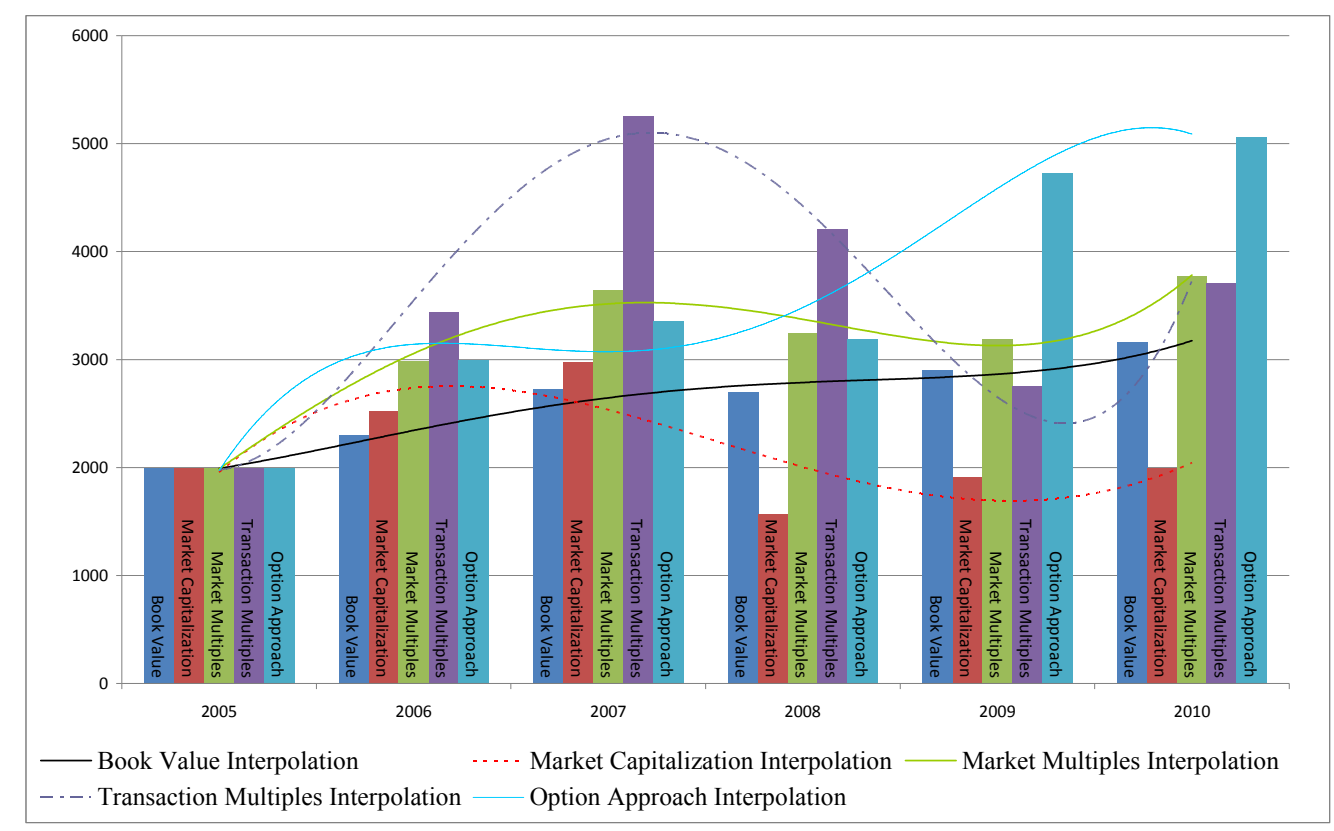


Table 4

Portfolio profits and losses (€)

\begin{tabular}{|c|c|c|c|c|c|}
\hline $\begin{array}{c}\text { End of financial } \\
\text { year report: }\end{array}$ & Book Value & $\begin{array}{c}\text { Market } \\
\text { Capitalization }\end{array}$ & $\begin{array}{c}\text { Market } \\
\text { Multiples }\end{array}$ & $\begin{array}{c}\text { Transaction } \\
\text { Multiples }\end{array}$ & $\begin{array}{c}\text { Option } \\
\text { Approach }\end{array}$ \\
\hline 2006 & 301.27 & 518.41 & 991.72 & $1,439.80$ & 997.28 \\
\hline 2007 & 428.41 & 453.68 & 653.87 & $1,820.84$ & 364.19 \\
\hline 2008 & -26.52 & $-1,404.37$ & -401.88 & $-1,055.68$ & -168.96 \\
\hline 2009 & 203.44 & 343.78 & -49.75 & $-1,445.32$ & $1,536.95$ \\
\hline 2010 & 259.35 & 87.50 & 576.22 & 947.43 & 329.63 \\
\hline Mean & 216.17 & -129.85 & 194.62 & 66.82 & 515.45 \\
\hline Standard deviation & 167.15 & 801.98 & 565.76 & $1,492.20$ & 662.39 \\
\hline
\end{tabular}

\section{Figure 2}

Portfolio profits and losses and polynomial interpolation (€)

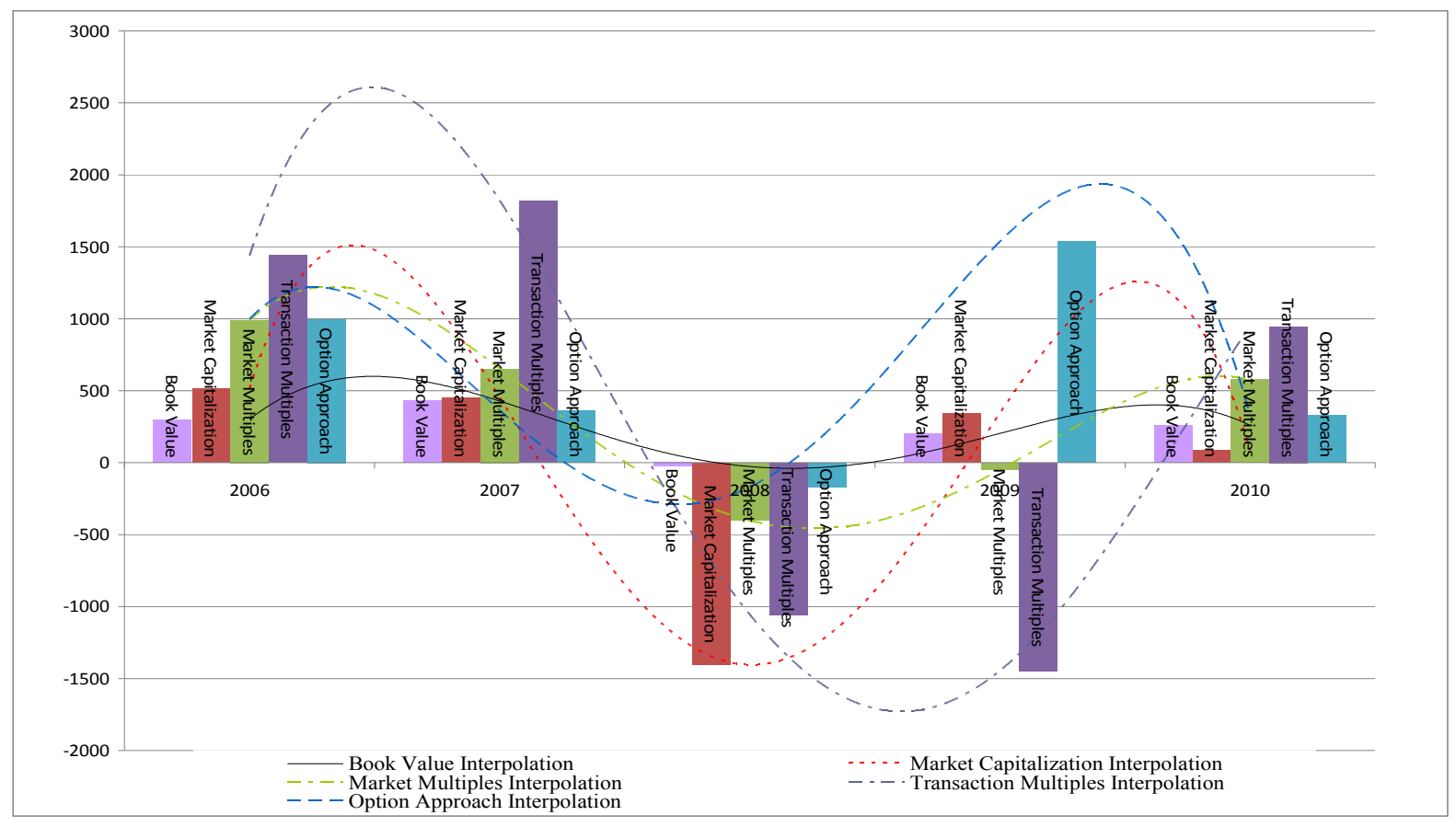


Table 5

\section{Portfolio Return}

\begin{tabular}{|c|c|c|c|c|c|}
\hline $\begin{array}{c}\text { End of financial } \\
\text { year report: }\end{array}$ & Book Value & $\begin{array}{c}\text { Market } \\
\text { Capitalization }\end{array}$ & Market Multiples & $\begin{array}{c}\text { Transaction } \\
\text { Multiples }\end{array}$ & Option Approach \\
\hline 2006 & $15.1 \%$ & $25.9 \%$ & $49.6 \%$ & $72.0 \%$ & $49.9 \%$ \\
\hline 2007 & $18.6 \%$ & $18.0 \%$ & $21.9 \%$ & $52.9 \%$ & $12.2 \%$ \\
\hline 2008 & $-1.0 \%$ & $-47.3 \%$ & $-11.0 \%$ & $-20.1 \%$ & $-5.0 \%$ \\
\hline 2009 & $7.5 \%$ & $21.9 \%$ & $-1.5 \%$ & $-34.4 \%$ & $48.1 \%$ \\
\hline 2010 & $8.9 \%$ & $4.6 \%$ & $18.0 \%$ & $34.3 \%$ & $7.0 \%$ \\
\hline Mean & $9.8 \%$ & $4.6 \%$ & $15.39 \%$ & $46.2 \%$ & $25.1 \%$ \\
\hline Standard deviation & $7.5 \%$ & $30.1 \%$ & $23.5 \%$ & $46.2 \%$ & $25.1 \%$ \\
\hline
\end{tabular}

\section{Figure 3}

\section{Portfolio Return}

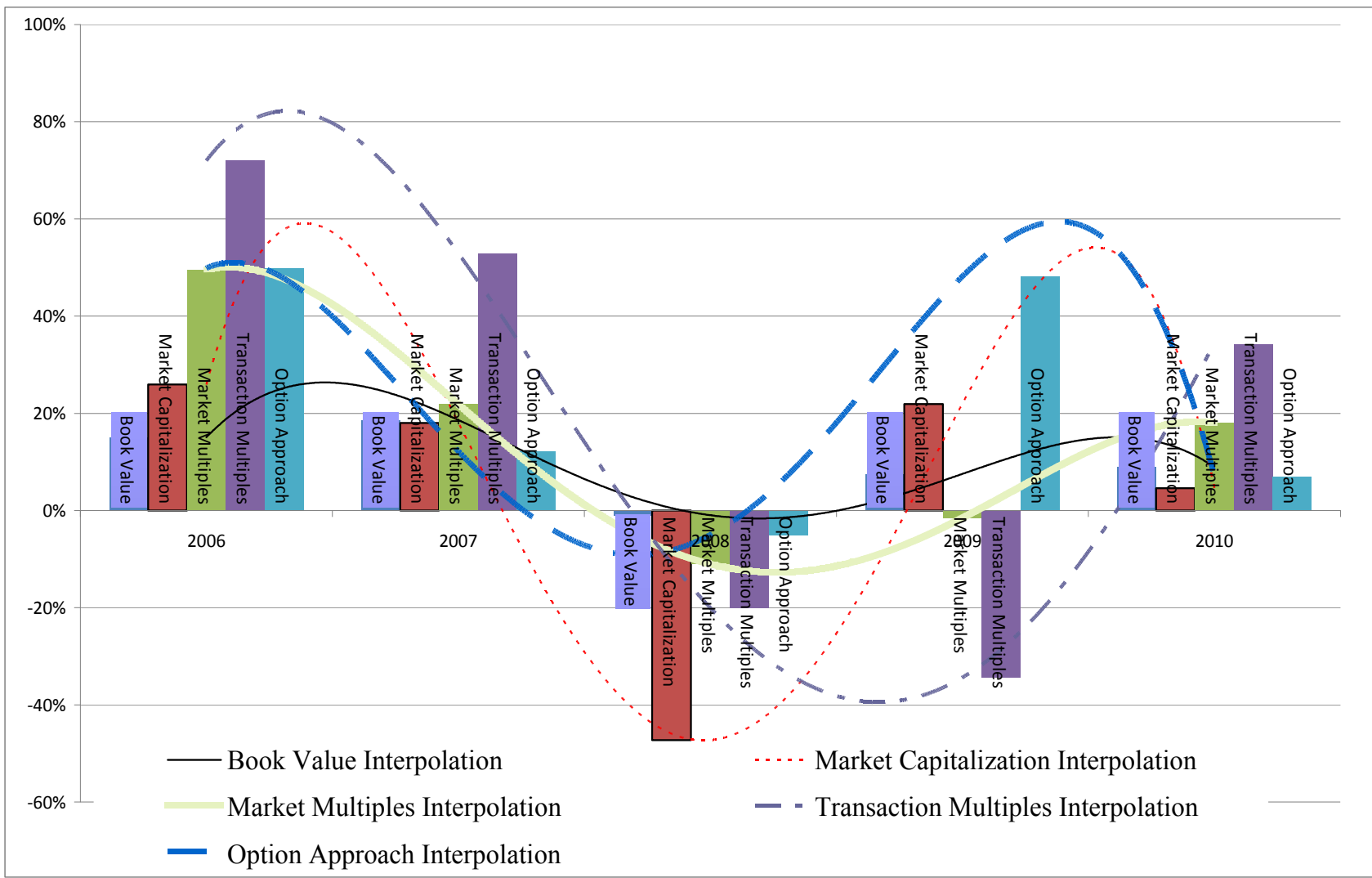


Table 6

Portfolio price-to-book value ratios $(x)$

\begin{tabular}{|c|c|c|c|c|c|}
\hline $\begin{array}{c}\text { End of financial } \\
\text { year report: }\end{array}$ & Book Value & $\begin{array}{c}\text { Market } \\
\text { Capitalization }\end{array}$ & $\begin{array}{c}\text { Market } \\
\text { Multiples }\end{array}$ & $\begin{array}{c}\text { Transaction } \\
\text { Multiples }\end{array}$ & $\begin{array}{c}\text { Option } \\
\text { Approach }\end{array}$ \\
\hline 2006 & 1.00 & 1.1 & 1.3 & 1.5 & 1.3 \\
\hline 2007 & 1.00 & 1.1 & 1.3 & 1.9 & 1.2 \\
\hline 2008 & 1.00 & 0.6 & 1.2 & 1.6 & 1.2 \\
\hline 2009 & 1.00 & 0.7 & 1.1 & 0.9 & 1.6 \\
\hline 2010 & 1.00 & 0.6 & 1.2 & 1.2 & 1.6 \\
\hline Mean & 1 & 0.84 & 1.19 & 1.35 & 1.32 \\
\hline Standard Deviation & 0.00 & 0.24 & 0.12 & 0.38 & 0.25 \\
\hline
\end{tabular}

Figure 4

Portfolio price-to-book value ratios

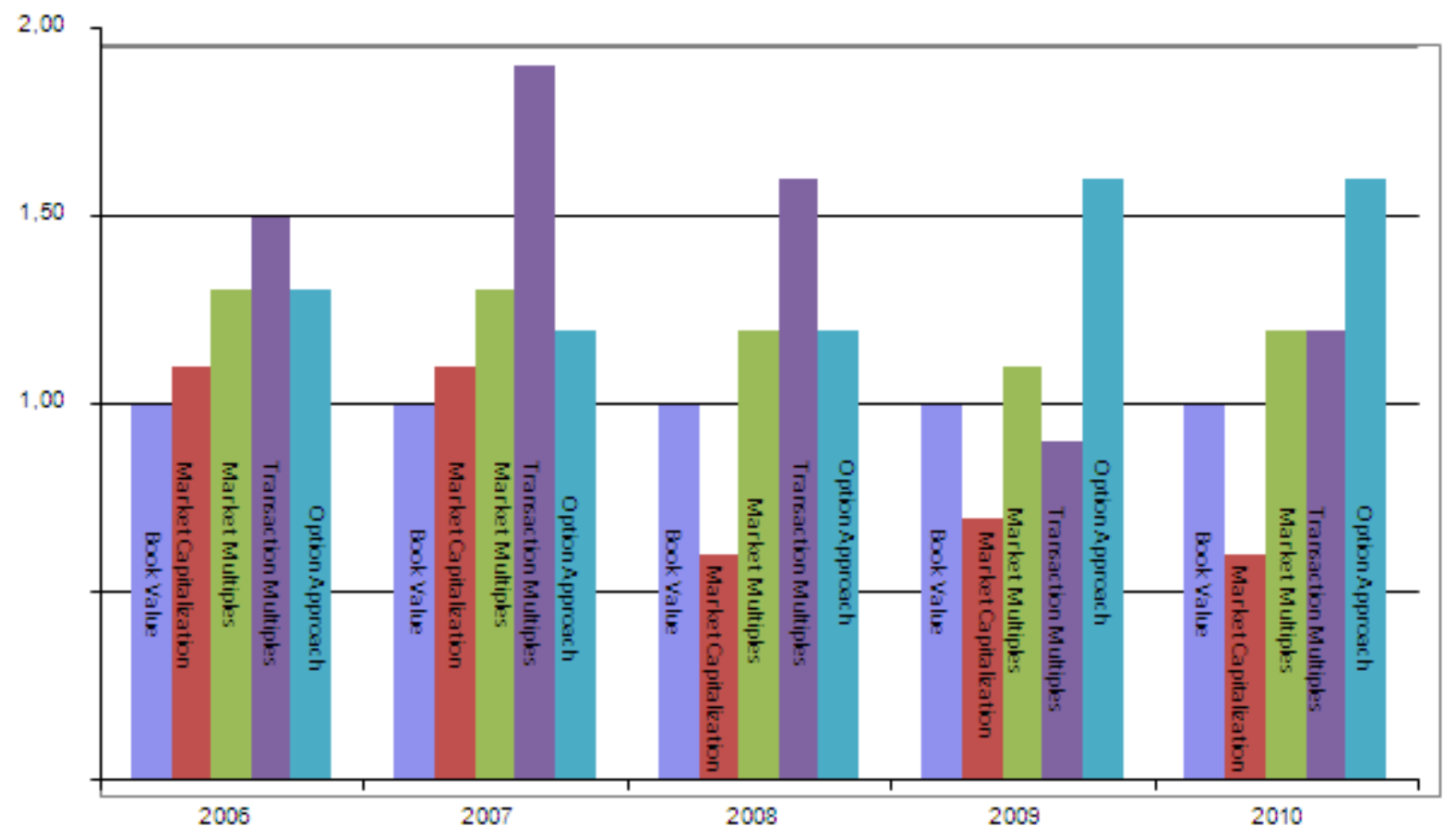




\section{WORKING PAPERS IN THE CAREFIN SERIES}

1/08 La stima del capitale economico a fronte del portafoglio crediti: un'introduzione alle nuove metodologie

2/08 Imperfect Predictability and Mutual Fund Dynamics: How Managers Use Predictors in Changing the Systematic Risk

3/08 Il sistema dualistico per la governance di banche e assicurazioni

4/08 Precautionary investments and vertical externalities: the role of private insurers in intergovernmental relations

5/08 I derivati climatici per il settore vitivinicolo

6/08 Market discipline in the banking industry. Evidence from spread dispersion

7/08 A Survey on Risk Management and Usage of Derivatives by Non-Financial Italian Firms

8/08 Hedge Funds: Ability Persistence and Style Bias

9/08 Cross-Industry Diversification: Integration, Bubble and Predictability

10/08 The Impact of Government Ownership on Banks' Ratings: Evidence from the European Banking Industry

11/08 A Framework for Assessing the Systemic Risk of Major Financial Institutions

12/08 Multidimensional Distance to Collapse Point and Sovereign Default Prediction

13/08 Search Costs and Mutual Fund Fee Dispersion

14/08 The Choice of Target's Advisor in Mergers and Acquisitions: the Role of Banking Relationship

15/08 Stochastic Mortality: the Impact on Target Capital

1/09 Regular(ized) Hedge Fund Clones

2/09 Loads and Investment Decisions

3/09 The role of Basel II in the subprime financial crisis: guilty or not guilty?

4/09 Why Larger Lenders obtain Higher Returns: Evidence from Sovereign Syndicated Loans

5/09 Crisi finanziaria, controlli interni e ruolo delle Autorità

6/09 Why do foreign banks withdraw from other nations

7/09 Do derivatives enhance or deter mutual fund risk-return profiles? Evidence from Italy

8/09 External Debt to the Private Sector and the Price of Bank Loans

9/09 Pricing insurance contracts following the cost of capital approach: some conceptual issues

10/09 Listed Private Equity Funds: IPO Pricing, J-Curve and Learning Effects

11/09 Rating changes: the European evidence

12/09 Beyond macroeconomic risk: the role of contagion in the italian corporate default correlation

13/09 Revisiting corporate growth options in the presence of state-dependent cashflow risk

14/09 Borrowing in Buyouts

15/09 Explaining Returns in Private Equity Investments

16/09 Banks’Loan Loss Provisioning: Procyclical Behaviour and Potential Solutions

17/09 Informed intermediation of longevity exposures

18/09 Regulations and soundness of insurance firms: international evidence

19/09 Project Finance Collateralised Debt Obligations: An Empirical Analysis on Spreads Determinants

20/09 Crashes and Bank Opaqueness

21/09 Investors' Distraction and Strategic Repricing Decisions

22/09 Italian labourers participation in private pension plans: an analysis of closed funds targeting specific industries

23/09 Diritto delle assicurazioni e diritto europeo: la prospettiva italiana

24/09 The Common Frame of Reference (CFR) of European Insurance Contract Law

01/10 Optimal time of annuitization in the decumulation phase of a defined contribution pension scheme

02/10 Three make a smile - dynamic volatility, skewness and term structure components in option valutation

03/10 On the role of behavioral finance in the pricing of financial derivatives: the case of the S\&P 500

04/10 Stabilizing Large Financial Institutions with Contingent Capital Certificates

05/10 Performance in private equity: why are general partnerships' owners important?

06/10 Operational Risk Modeling: An Evaluation of Competing Strategies

07/10 Ownership Structure, Board Composition And Investors’ Protection: Evidence From S\&P 500 Firms

08/10 Towards A New Framework For Liquidity Risk 
09/10 Too-Big-to-Fail” and its Impact on Safety Net Subsidies and Systemic Risk

10/10 Private benefits of control in the banking industry: a cross-country analysis

11/10 Reaching Nirvana With A Defaultable Asset?

12/10 Measuring Systemic Risk in the Finance and Insurance Sectors

13/10 On Regulation, Supervision, (De)leveraging and Banking Competition: Harder, Better, Faster, Stronger?

14/10 Variable Annuities: Risk Identification and Risk Assessment

15/10 CEO Remuneration and Bank Default Risk: Evidence from the US and Europe

16/10 The Basel Committee Proposals For Capital Adequacy Reform: A Critical Analysis

17/10 Risk Measures with Contractual Default

18/10 Hundred Years of British Firm - Bank Relationships:Why the Transition to Multiple Banking?

19/10 Hedge Fund Systemic Risk Signals

20/10 Shareholder Rights and Syndicate Structure

21/10 Bank Capital under Basel 3: Open Issues and foreseeable Effects

22/10 Regulations and Insurance Consumption

23/10 Are sanctions effective in improving bank performance? A study on supervision and administrative sanctions upon Italian banks during the 1998-2009 period

24/10 In- and out-of-court debt restructuring in the presence of credit default swaps

25/10 Systemic Risk and Network Formation in the Interbank Market

26/10 Corporate Governance and Pension Fund Performance

27/10 Macroeconomic Uncertainty, Difference in Beliefs, and Bond Risk Premia

28/10 New efficient frontier: Can structured products really improve risk-return profile?

01/11 La crisi finanziaria e Basilea 3: origini, finalità e struttura del nuovo quadro regolamentare

02/11 Once bitten twice shy? A study on the effectiveness of administrative sanctions to discipline bank board members

03/11 The Insurance by My Side: Better Risk Assessment for Smarter Insurance Decisions

04/11 Regulations, Institutions and Income Smoothing by Managing Technical Reserves: International Evidence from the Insurance Industry
05/11 Trade Credit and Firm Financial Constraints: Evidence From The Great Recession

06/11 Corporate Liquidity

07/11 Bank Regulation, Credit Ratings, and Systematic Risk

08/11 Il dilemma “Too Big To Fail”:integrare regole e mercato

09/11 Are Target-Date Funds Too Risky?

10/11 Bank Earnings,Opacity,and Stock Trading Properties

11/11 The impact of Solvency II type regulations on the performance of insurance firms:evidence from the European Union

12/11 Risk Analysis with Contractual Defaul:Do Covenants Matter?

13/11 Firm Lies in the Eye of the Beholder

14/11 A New Framework for Funds Transfer Pricing

15/11 Executive Board Composition and Bank Risk Taking

16/11 Minimum Trade Unit Regulation and Market Quality

01/12 Fair Value Measurement for Private Equities: a Plus or a Minus for Stakeholders? 
The working papers by Carefin, Bocconi’s Centre for Applied Research in Finance are made possibile by the following Institutions

ALLIANZ

ARCA SGR

ARCA VITA

ASSICURAZIONI GENERALI

AVIVA ITALIA HOLDING.

BANCA POPOLARE DI MILANO

BANCASSURANCE POPOLARI
CARDIF ASSICURAZIONI

CARIGE AM SGR

CATTOLICA ASSICURAZIONI

DELOITTE CONSULTING

INTESA SANPAOLO

SARA ASSICURAZIONI

Copyright

Carefin, Università Bocconi 


\section{CAREFIN}

Centre for Applied Research in Finance

Università Bocconi

via Röntgen 1

I-20136 Milano

tel. +39 025836.5908/07/06

fax +39025836.5921

carefin@unibocconi.it

www.carefin.unibocconi.it 